\title{
Proportions of Organic Waste in the Process of Composting
}

\section{Thayane Leonel Alves ${ }^{1}$ \\ Evandro Freire Lemos ${ }^{2}$ \\ José De Arruda Barbosa ${ }^{3}$ \\ Gabriela Mourão De Almeida ${ }^{4}$ (DD \\ Antônio Michael Pereira Bertino ${ }^{5}$}

${ }^{1 ., 4}$ Master Student, Postgraduated Graduation in Agronomy (Science of the Soil), Universidade Estadual Paulista (UNESP), Jaboticabal, São Paulo, Brazil.

'Email: thavaneleonel@hotmail.com Tel: +5537999696029

${ }^{3}$ Email: josearruda777@gmail.com Tel:+5581998072060

¿Email: gabrielamouraodealmeida@gmail.com Tel: +5591982353699

'Agronomist, Prof. Dr., Universidade do Estado De Minas Gerais (UEMG), Passos, Minas Gerais, Brazil.

2Email:evandro.lemos@uemg.brTel: +5535992540700

${ }^{5}$ PhD in Agronomy (Plant Production), Universidade Estadual Paulista (UNESP), Jaboticabal, São Paulo, Brazil.

sEmail:ampbantonio@gmail.com Tel:+5583999494765

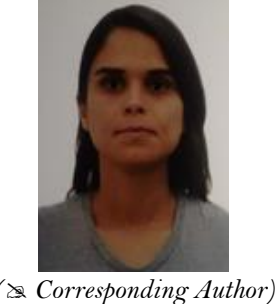

( Corresponding Author)

\section{Abstract}

The objective of this study was to evaluate the composting process made from different combinations of organic residues and to gain agronomic knowledge about the final product. The experimental design was randomized blocks, with five treatments: T1 - 50\% sawdust, $35 \%$ fruit / vegetable husks and 15\% coffee grounds and filter; T2 - 50\% sawdust, $30 \%$ fruit / vegetable peels and $20 \%$ coffee grounds and filter; T3 - 60\% sawdust, $30 \%$ fruit / vegetable peel and $10 \%$ coffee grounds and filter; T4 - 60\% sawdust, $20 \%$ fruit / vegetable peels and $20 \%$ coffee grounds and filter; and T5 - 70\% sawdust, $20 \%$ fruit / vegetable peels and $10 \%$ coffee grounds and filter and four replicates. The parameters monitored daily were temperature and humidity. After 140 days of initiation, the sample was collected for analysis. The material was analyzed in the soil and leaf fertility laboratory of the UEMG Unit Passos to determine the organic matter content, $\mathrm{C} / \mathrm{N}$ ratio, $\mathrm{pH}$ and macronutrient and micronutrient content. Treatments 1 and 2 presented the best values in relation to the other treatments, due to the lower percentage of sawdust. The low ambient temperatures in the composting process, the high $\mathrm{C} / \mathrm{N}$ ratio of the sawdust, the proportion of residues used in the formation of the compost and the volume of the material may have had a negative influence on the composting process.

Keywords: Biological process, Decomposition, Degradation, Mineralization, Nutrients, Organic fertilizer, Organic waste.

Citation | Thayane Leonel Alves; Evandro Freire Lemos; José De Arruda Barbosa; Gabriela Mourão De Almeida; Antônio Michael Pereira Bertino (2019). Proportions of Organic Waste in The Process of Composting. Agriculture and Food Sciences Research, 6(1): 15-21.

History:

History:

Received: 25 October 2018

Revised: 2 December 2018

Accepted: 7 January 2019

Published: 20 March 2019

Licensed: This work is licensed under a Creative Commons

Attribution 3.0 License $(\mathrm{cc}) \mathbf{B}$

Publisher: Asian Online Journal Publishing Group
Contribution/Acknowledgement: All authors contributed to the conception and design of the study.

Funding: This study was financed in part by the Coordenação de Aperfeiçoamento de Pessoal de Nível Superior - Brasil (CAPES) - Finance Code 001.

Competing Interests: The authors declare that they have no conflict of Competing

Transparency: The authors confirm that the manuscript is an honest, accurate, and transparent account of the study was reported; that no vital features of the study have been omitted; and that any discrepancies from the study as planned have been explained.

Ethical: This study follows all ethical practices during writing.

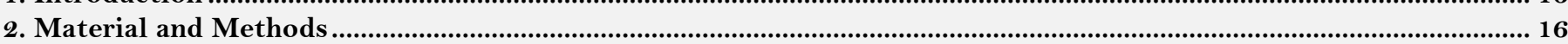

3. Results and Discussion ................... 17

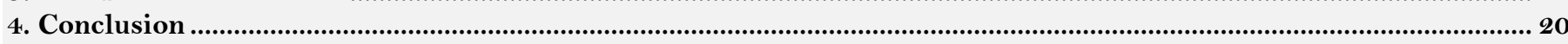

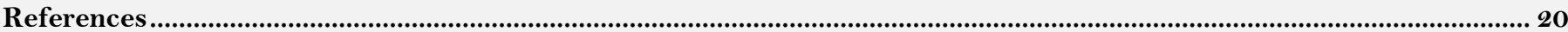




\section{Introduction}

Every day in Brazil, 260000 tons of solid waste are produced, 53\% of which consists of organic waste, $25 \%$ paper and cardboard, $3 \%$ plastic, $2 \%$ glass, $2 \%$ metal and $15 \%$ others, that only $2 \%$ of this total is reused. In order to increase the percentage of reuse, it is important to encourage the recycling of waste because of its environmental impact [1]. In Brazil, almost 50\% of municipalities still use "open dumps". The volume of garbage produced by the Brazilian population increases annually, which is largely discarded incorrectly [2]. In 2016, CALIXTO [3] affirms that selective collection is fundamental to reduce the environmental impact caused by the country's dumps, on average, each Brazilian produces $1 \mathrm{~kg}$ of garbage per day, being $365 \mathrm{~kg}$ per year, he announced that $47 \%$ of The rural population of the country does not have any type of garbage collection.

The bad management of garbage, besides causing environmental problems, can cause social problems: many collectors guarantee the sustenance of their families by selling what is found in garbage dumps and even minors doing this type of work. The treatment of organic waste is an excellent alternative from the environmental point of view, in order to achieve a solution for this excess, being an option to produce organic fertilizers [4]. Due to the large amount of organic waste produced by Brazilian cities, the work theme becomes relevant because it addresses the use of these residues through the composting process, in the formation of organic fertilizer, being an alternative for the use of waste and a fertilizer option for farmers.

Composting is the procedure performed by several organisms where the biodegradable organic fraction of the waste is decomposed under controlled aerobic conditions and other parameters [5]. For Pereira [6] composting is an aerobic biological process, obtained by the controlled biodegradation of organic waste, generating an organic compound.

The composting process is carried out by the microorganisms present in the residues, provided that the conditions of temperature, aeration and humidity are ideal [7]. The final product of the composting is a mass of fine texture and homogeneous, without characteristic smell of the residues that gave rise to it (excellent conditioner and improver of the properties of the soil). It also results in a dark liquid of bad smell called slurry, which is caused if the composting is conducted improperly Nunes [8]. Nunes [9] mentions that the use of organic fertilizer brings with advantage an increase in the cation exchange capacity; aggregation of particles to the soil, reducing the erosive process; stores more water because it increases water retention capacity; decreases temperature oscillations during the day; and increases the availability of phosphorus.

Organic fertilizers are specified according to Ordinance $n^{\circ} 1$ of March $4^{\text {th }}, 1983$. In the compost it is necessary to have a minimum of $40 \%$ of organic matter, a minimum of $1 \%$ of nitrogen, a maximum of $40 \%$ of humidity, a maximum of $18 / 1 \mathrm{C} / \mathrm{N}$ ratio, $\mathrm{pH}$ minimum of 6.0 , minimum of $1 \%$ of calcium, minimum of $0.5 \%$ of magnesium, minimum of $1 \%$ of sulfur, minimum of $0.02 \%$ of boron, minimum of $0.1 \%$ of iron, minimum of $0.05 \%$ of manganese, minimum of $0.1 \%$ of molybdenum and minimum of $0.1 \%$ of zinc [10].

Custodio, et al. [11] define that the organic materials that can be used to form the compound are practically all kitchen waste and garden waste, being: rest of vegetables and fruits; coffee powder and its filter; eggshell; tea bags; dry straw and grass; branches, leaves, bark and tree pruning, sawdust; among others. And what cannot be put are materials that may have some kind of contaminating or polluting material and non-puttable materials of difficult decomposition. Examples: Feces of domestic animals; toilet paper; diapers; ash and cigar stump; wood; coal; barbecue meat; fish; fat; cheeses; sick plants; weeds; glass; metals; plastics; leather; eraser; fabric; etc.

Organic materials discarded in the trash are classified as greens (rest of raw vegetables, rest and fruit peels, coffee grounds and filter, rest of bread, eggshell, tea bag, etc.) and brown (sawdust, leaves, bark, dried straw, hay, grass trimming, tree pruning, etc.). The greens have in their composition a higher proportion of nitrogen, $\mathrm{C} / \mathrm{N}$ less than 30/1, has a high moisture content and decomposes faster; and browns that have the highest proportion of carbon in relation to nitrogen, $\mathrm{C} / \mathrm{N}$ higher than 30/1. Examples: coffee husk - C / N: 30; coffee grounds, fine - C / $\mathrm{N}$ : 32; coffee grounds, coarse - C / N: 33; shaving - C / N: 391; sawdust - C / N: 482; green coconut - C / N: 78; coconut fiber - C / N: 144; of coal - C / N: 186 [12].

The decomposition is where all the organic material will be placed. It can be done in various ways being they forming a pile or pyramid in a yard, digging a hole in the ground, wooden or plastic container, among others. This will depend on the creativity of each person and availability of material, because the ideal is that you do not buy the decomposer but rather you create it. This decomposer should be placed in an easily accessible, low slope, protected from wind, direct sunlight and animals [13].

The decomposer can be classified into three types, according to Ishimura, et al. [14]: Composting in piles, Composting in beds and Compost in cube or boxes. Composting in piles uses small volumes with measures smaller than three meters in diameter. On the other hand, the composting in rows uses large volumes, being the trapezoidal format, with two meters in the lower base, one in the upper base and indeterminate length. Cube or box composites use small volumes, can be constructed of wood, masonry or other material, and in varying sizes.

The three phases of the composting process described by Fetti [15] are defined as mesophilic, thermophilic and the final stage of maturation. The first phase, mesophilic, lasts approximately 15 days, bacteria survive at temperatures around $40^{\circ} \mathrm{C}$, and they metabolize the simplest nutrients. The second phase, thermophilic, is the longest, extends for two months, bacteria and fungi called thermophiles, act at high temperature $\left(65-70{ }^{\circ} \mathrm{C}\right)$, degrading more complex molecules. The last stage, maturation phase, can persist for one to two months, in which the temperature, microbiological activity and acidity decrease.

Therefore, the purpose of this study was to evaluate the composting process made from different combinations of organic waste and to gain agronomic knowledge about the final product.

\section{Material and Methods}

This study was conducted at the Experimental Farm of the State University of Minas Gerais (UEMG) unit Passos, in Passos, MG $\left(20^{\circ} \mathrm{S}\right.$ latitude and $46^{\circ} \mathrm{W}$ longitude of Greenwich). The study area is located at an average elevation of $700 \mathrm{~m}$, with average annual temperature: maximum $22.8^{\circ} \mathrm{C}$ and minimum of $21.7^{\circ} \mathrm{C}$; and average annual rainfall of $1709.4 \mathrm{~mm}$, dry winters and rainy summers, classified climate, according to Köppen, as Cwa, subtropical climate / tropical altitude climate, with dry winter and hot summer (tropical rainy). 
In the composting process the following wastes were used: sawdust, fruit / vegetable waste and coffee grounds and filter. These residues were purchased from the restaurant and departments of UEMG Unidad Passos, from the various furniture factories in Passos, fruit and vegetable markets, supermarkets and private residences. The treatments were defined by mixing the organic compounds in combinations in the following proportions Table 1 :

Table-1. Description of the treatments of the project. Passos, 2017.

\begin{tabular}{c|l}
\hline TREATMENTS & DESCRIPTION \\
\hline $\mathrm{T} 1$ & $50 \%$ sawdust, $35 \%$ fruit / vegetable peel and $15 \%$ coffee grounds and filter. \\
\hline $\mathrm{T} 2$ & $50 \%$ sawdust, $30 \%$ fruit / vegetable peel and $20 \%$ coffee grounds and filter. \\
\hline $\mathrm{T} 3$ & $60 \%$ sawdust, $30 \%$ fruit / vegetable peel and $10 \%$ coffee grounds and filter. \\
\hline $\mathrm{T} 4$ & $60 \%$ sawdust, $20 \%$ fruit / vegetable peel and $20 \%$ coffee grounds and filter. \\
\hline $\mathrm{T} 5$ & $70 \%$ sawdust, $20 \%$ fruit / vegetable peel and $10 \%$ coffee grounds and filter. \\
\hline
\end{tabular}

The compost was produced in reusable plastic gallons with a volume of 20 liters, which were used to commercialize mineral water, making a longitudinal cut in them to remain lying down, and holes in the bottom for the slurry to run. The parameters temperature and humidity were monitored during the maturation period of the compost. The temperature was determined with the aid of a thermometer, introducing it into the compound at three points. For the monitoring of moisture, the hand test was performed Figure 1 [16] according to the three parameters of the figure the wetting of the compost was done and when wet, it was also stirred so that the process occurred under ideal conditions.
a)
b)
C)

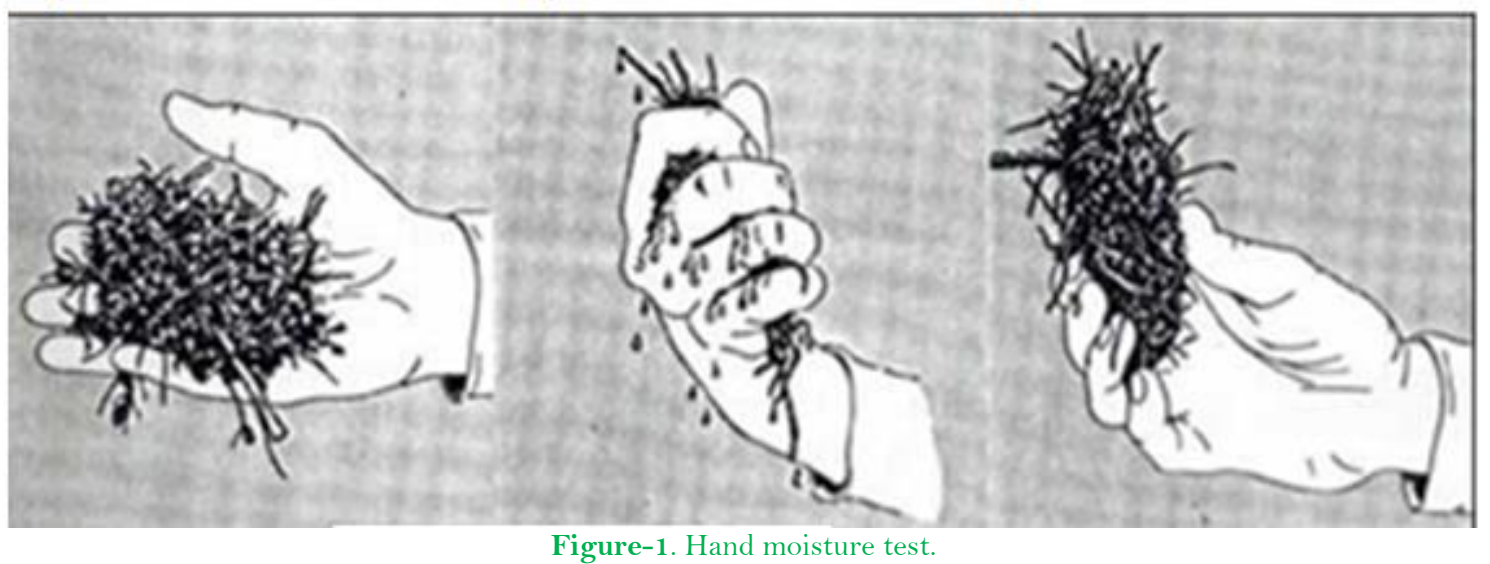

Note: Legend: a) When you open your hand, the sample crumbles, it is too dry. b) When you shake your hand, a liquid runs between your fingers, it is too wet. c) When opening the hand, the sample forms an acorn, it is in the ideal humidity. Source: Moraes [16].

After the composting process was completed (temperature reduction and no odor, after 140 days of the start of the process), the sample was collected from the recycled waste to perform the analysis. Each sample was dried in greenhouses at $60^{\circ} \mathrm{C}$, until constant weight, to determine dry matter and humidity. They were ground in a mill and the material was analyzed in the soil and leaf fertility laboratory of UEMG Unit Passos for determination of organic matter content, $\mathrm{C} / \mathrm{N}$ ratio, $\mathrm{pH}$ and macronutrient and micronutrient content.

The experiment was conducted in a causal block design (DBC) with five treatments (five different waste compositions) and five replicates. The results were tabulated in a spreadsheet, to perform the statistical analyzes that were carried out with the help of the GENES computer application to identify the treatments that generated superior agronomic compound [17].

\section{Results and Discussion}

The results of the characterization of the different residues are shown in Table 2. It is observed that the humidity of the residues is within the expected, since the fruit and vegetable skins have a large amount of water (86.8\%), sawdust is a material (2.18) and the coffee powder was not too humid (51.38\%), since it had been dried before composting. Macros and micronutrients presented fruit and vegetable peels as nutrient richer material than other residues. It can be observed that sawdust presents a $\mathrm{C} / \mathrm{N}$ ratio (114.84), which is much higher than that referred to as limiting the composting process. Regarding organic matter, sawdust and coffee powder had a higher value than fruit and vegetable peels, this may be due to the fact that these materials are already in the most advanced decomposition stage. As for the $\mathrm{pH}$, the fruit / vegetable peels presented better value in relation to coffee powder and sawdust.

The temperature variation in the composting process Figure 2 didn't occur as described in the literature, where it shows that in the first stage, the temperature is around $40^{\circ} \mathrm{C}$, then in the second phase, thermophilic, it acts between $65^{\circ}-70^{\circ} \mathrm{C}$ and final stage of maturation, the temperature gradually decreases. This may have been influenced by the proportions of the residues, since even in winter (May to October), when the temperature ranged from 8 to $33{ }^{\circ} \mathrm{C}$ Figure 3, Arrigoni, et al. [18] in Argentina, where the average annual temperature is $8.4{ }^{\circ} \mathrm{C}$, performed a work with composting and the temperature of the process varied according to the literature. Several authors have observed different behavior of temperature in the composting process, this indicates that average values of temperature should not be considered as standard [19]; [20]; [21]; [22]; [23]; [24]. 
Table-2. Characterization of the residues used in the composting process. Passos, MG.

\begin{tabular}{|c|c|c|c|}
\hline \multirow{2}{*}{ Characteristics } & \multicolumn{3}{|c|}{ Residues } \\
\hline & Fruit / vegetable peel & Coffee grounds and filter & Sawdust \\
\hline Humidity (\%) & 86.81 & 51.38 & 2.18 \\
\hline M.S. (\%) & 13.19 & 48.62 & 97.82 \\
\hline $\mathrm{N}(\mathrm{g} / \mathrm{kg})$ & 20.37 & 21.42 & 4.13 \\
\hline $\mathrm{P}(\mathrm{g} / \mathrm{kg})$ & 2.54 & 1.37 & 0.07 \\
\hline $\mathrm{K}(\mathrm{g} / \mathrm{kg})$ & 20.95 & 11.31 & 0.21 \\
\hline $\mathrm{Ca}(\mathrm{g} / \mathrm{kg})$ & 10.15 & 0.91 & 0.36 \\
\hline $\operatorname{Mg}(\mathrm{g} / \mathrm{kg})$ & 1.50 & 1.81 & 0.78 \\
\hline $\mathrm{S}(\mathrm{g} / \mathrm{kg})$ & 1.88 & 1.31 & 0.30 \\
\hline $\mathrm{B}(\mathrm{mg} / \mathrm{kg})$ & 22.87 & 9.07 & 5.34 \\
\hline $\mathrm{Cu}(\mathrm{mg} / \mathrm{kg})$ & 8.57 & 19.14 & 0.58 \\
\hline $\mathrm{Fe}(\mathrm{mg} / \mathrm{kg})$ & 431.42 & 533.77 & 155.18 \\
\hline $\mathrm{Mn}(\mathrm{mg} / \mathrm{kg})$ & 45.42 & 36.16 & 46.99 \\
\hline $\mathrm{Zn}(\mathrm{mg} / \mathrm{kg})$ & 17.05 & 8.40 & 8.30 \\
\hline Total carbon $(\%)$ & 37.26 & 49.09 & 47.43 \\
\hline Carbon / Nitrogen Ratio & 18.29 & 22.92 & 114.84 \\
\hline M.O. (\%) & 64.24 & 84.63 & 81.77 \\
\hline $\mathrm{pH}$ & 5.64 & 4.95 & 4.52 \\
\hline
\end{tabular}

40.0

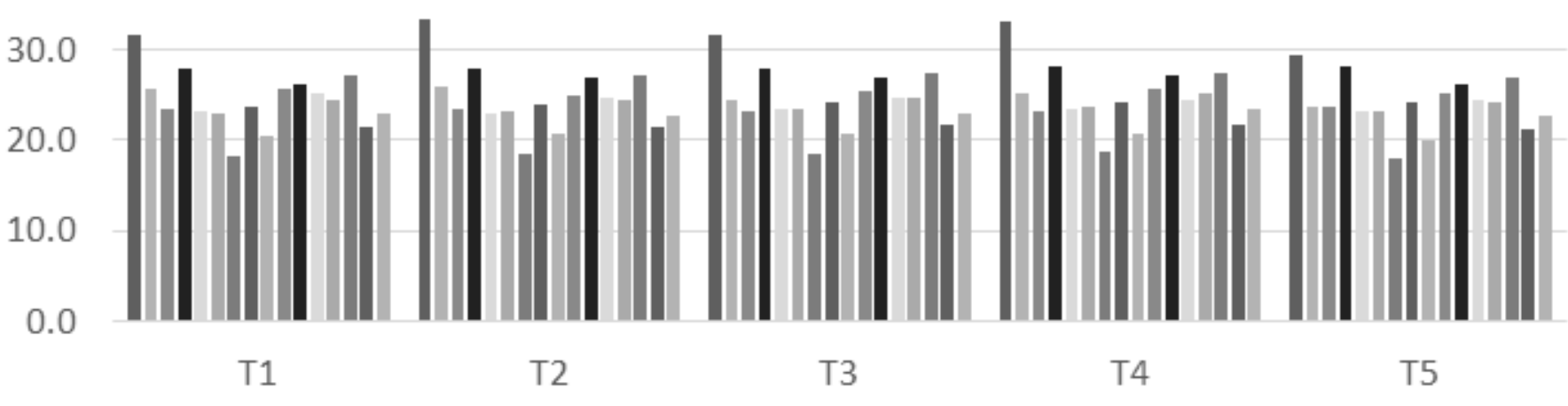

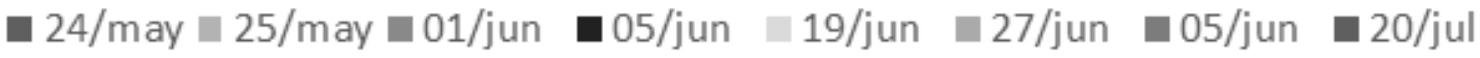

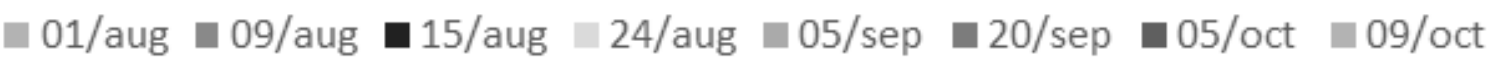

Figure-2. Temperature variation during the composting process.

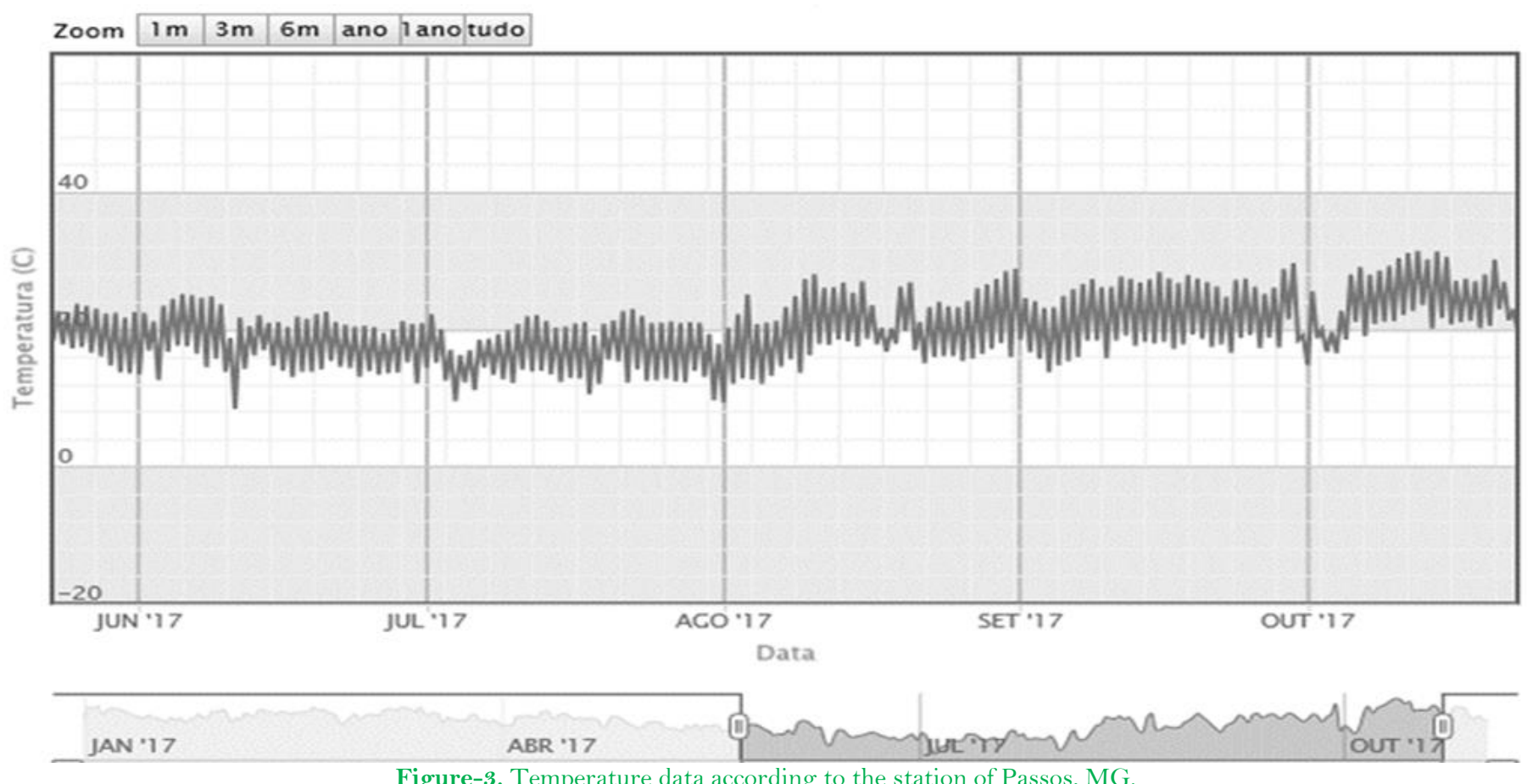

Source: Instituto Nacional de Meteorologia (INMET) [25].

At the end of the process, treatment 1 showed a $67.7 \%$ humidity on average, treatment 2 with $67.4 \%$, treatment 3 with $64.7 \%$, treatment 4 with $65.3 \%$ and treatment 5 with $65.2 \%$. According to the Brazilian legislation, the compost must have a humidity of at most $40 \%$, therefore, these results are not in accordance with the legislation, being necessary to let the compost dry.

By means of the statistical analysis, it can be verified that in treatments 1 and 2 the average values for macronutrients: nitrogen, phosphorus, potassium and sulfur were higher than the other treatments, treatments 3 and 4 presented intermediate values for these macronutrients and treatment 5 resulted in the lowest values for 
these same variables. However, for calcium and magnesium, there was no difference between treatments Table 3 . Treatment 5 presents in its composition a greater amount of sawdust $(70 \%)$, the material being poorer chemically presented in Table 2 previously, which explains the worse final performance of the compound. Treatments 3 and 4 present intermediate sawdust content $(60 \%)$ and treatments 1 and 2 have the lowest amount of sawdust in their composition $(50 \%)$, which is in agreement with the results of macronutrients found, that is, a correlation negative relationship between the amount of sawdust of the compound and the nitrogen, phosphorus, potassium and sulfur contents of the final compound. Information on the chemical composition of the domestic compound is very scarce, there are no reference values.

\begin{tabular}{l|c|c|c|c|c|c}
\hline \multirow{2}{*}{ Treatment } & \multicolumn{5}{c}{ Mean (g/kg) } \\
\cline { 2 - 6 } & Nitrogen & Phosphorus & Potassium & Calcium & Magnesium & Sulfur \\
\hline T1 (50\% S; 35\% CFH; 15\% BCF) & $13.65 \mathrm{a}$ & $0.856 \mathrm{a}$ & $7.928 \mathrm{a}$ & $1.870 \mathrm{a}$ & $1.150 \mathrm{a}$ & $1.088 \mathrm{a}$ \\
\hline T2 (50\% S; 30\% CFH; 20\% BCF) & $12.57 \mathrm{a}$ & $0.816 \mathrm{a}$ & $7.640 \mathrm{a}$ & $1.986 \mathrm{a}$ & $1.114 \mathrm{a}$ & $0.966 \mathrm{a}$ \\
\hline T3 (60\% S; 30\% CFH; 10\% BCF) & $9.70 \mathrm{~b}$ & $0.610 \mathrm{~b}$ & $6.192 \mathrm{~b}$ & $2.638 \mathrm{a}$ & $1.024 \mathrm{a}$ & $0.772 \mathrm{~b}$ \\
\hline T4 (60\% S; 20\% CFH; 20\% BCF) & $10.27 \mathrm{~b}$ & $0.536 \mathrm{~b}$ & $5.328 \mathrm{~b}$ & $1.488 \mathrm{a}$ & $1.210 \mathrm{a}$ & $0.724 \mathrm{~b}$ \\
\hline T5 (70\% S; 20\% CFH; 10\% BCF) & $7.93 \mathrm{c}$ & $0.432 \mathrm{c}$ & $3.976 \mathrm{c}$ & $1.250 \mathrm{a}$ & $1.002 \mathrm{a}$ & $0.596 \mathrm{~b}$ \\
\hline Note: Averages followed by the same letter in the column do not differ from each other by the Scott \& Knott test at 5\% probability. Caption: S
\end{tabular}

(sawdust); CFH (fruit peel / vegetables); BCF (coffee grounds and filter).

These treatments received the highest percentage of coffee grounds (15\%, $20 \%$ and $20 \%$, respectively), which according to the table 5 shows very high values of this micronutrient. Treatment 1 was higher than the others for the final manganese content Table 4. The boron, iron and zinc elements showed no difference between the means of the evaluated treatments.

Table-4. Means of micronutrient. Passos, 2017

\begin{tabular}{l|c|c|c|c|c}
\hline \multirow{2}{*}{ Treatment } & \multicolumn{5}{|c}{ Mean (mg/kg) } \\
\cline { 2 - 6 } & Boron & Copper & Iron & Manganese & Zinc \\
\hline T1 (50\% S; 35\% CFH; 15\% BCF) & $12.422 \mathrm{a}$ & $7.962 \mathrm{a}$ & $311.58 \mathrm{a}$ & $70.052 \mathrm{a}$ & $11.708 \mathrm{a}$ \\
\hline T2 (50\% S; 30\% CFH; 20\% BCF) & $10.634 \mathrm{a}$ & $8.228 \mathrm{a}$ & $284.16 \mathrm{a}$ & $62.618 \mathrm{~b}$ & $9.858 \mathrm{a}$ \\
\hline T3 (60\% S; 30\% CFH; 10\% BCF) & $11.344 \mathrm{a}$ & $5.634 \mathrm{~b}$ & $373.57 \mathrm{a}$ & $57.986 \mathrm{~b}$ & $12.187 \mathrm{a}$ \\
\hline T4 (60\% S; 20\% CFH; 20\% BCF) & $9.514 \mathrm{a}$ & $7.072 \mathrm{a}$ & $301.27 \mathrm{a}$ & $55.258 \mathrm{~b}$ & $11.654 \mathrm{a}$ \\
\hline T5 (70\% S; 20\% CFH; 10\% BCF) & $9.440 \mathrm{a}$ & $4.630 \mathrm{~b}$ & $262.76 \mathrm{a}$ & $56.868 \mathrm{~b}$ & $10.688 \mathrm{a}$ \\
\hline
\end{tabular}

Note: Averages followed by the same letter in the column do not differ from each other by the Scott \& Knott test at $5 \%$ probability. Caption: S (sawdust); CFH (fruit peel / vegetables); BCF (coffee grounds and filter).

It was verified that for the $\mathrm{pH}$ variable, treatments 1,2 and 3 (6.582, 6.492 and 6.610 respectively) were superior to treatments 4 and 5 (6.194 and 6.238 respectively), which did not differ among them Table 5. The treatments 1, 2 and 3 presented the highest proportion of fruit / vegetable peels (35\%, 30\% and 30\%, respectively), and this residue presented the ideal $\mathrm{pH}$ value. According to Barroso, et al. [26]; Souza, et al. [27]; Kampf [28] ideal values for $\mathrm{pH}$ of a substrate rotates around 6.0 to 6.5, symptoms of nutritional deficiency of plants are found on substrates with pH below 5.0.

For the variables: carbon and organic matter, there was no difference between the treatments. However, for the Carbon / Nitrogen ratio, treatment 5 was superior to the other treatments. The treatments 3 and 4 were equal to each other and were higher than treatments 1 and 2 , which did not differ between them. The higher the $\mathrm{C} / \mathrm{N}$ ratio, the slower the mineralization of the material, which in this case is negative Table 5 . This result is in agreement with the proportion of sawdust used in each treatment, since this residue presented a high $\mathrm{C} / \mathrm{N}$ ratio. It was observed that treatments with lower $\mathrm{C} / \mathrm{N}$ ratio (treatments 1 and 2 ) presented the lowest proportion of sawdust $(50 \%)$, treatments 3 and 4 presented intermediate $\mathrm{C} / \mathrm{N}$ ratio and received ratios of sawdust also intermediate $(60 \%)$, while treatment 5 presented the highest $\mathrm{C} / \mathrm{N}$ ratio and the highest proportion of sawdust $(70 \%)$.

\begin{tabular}{c|c|c|c|c} 
Table-5. Averages of the percentage of carbon, the C/N ratio, the percentage of organic matter (M.O.) and pH. Passos, 2017. \\
\cline { 2 - 5 } Treatment & \multicolumn{4}{c}{ Mean } \\
\cline { 2 - 5 } & \% Carbon & C/N & \% M.O. & pH \\
\hline T1 (50\% S; 35\% CFH; 15\% BCF) & $40.348 \mathrm{a}$ & $29.884 \mathrm{c}$ & $69.560 \mathrm{a}$ & $6.582 \mathrm{a}$ \\
\hline T2 (50\% S; 30\% CFH; 20\% BCF) & $42.264 \mathrm{a}$ & $34.348 \mathrm{c}$ & $73.210 \mathrm{a}$ & $6.492 \mathrm{a}$ \\
\hline T3 (60\% S; 30\% CFH; 10\% BCF) & $39.978 \mathrm{a}$ & $42.294 \mathrm{~b}$ & $68.920 \mathrm{a}$ & $6.610 \mathrm{a}$ \\
\hline T4 (60\% S; 20\% CFH; 20\% BCF) & $42.502 \mathrm{a}$ & $41.518 \mathrm{~b}$ & $73.274 \mathrm{a}$ & $6.194 \mathrm{~b}$ \\
\hline T5 (70\% S; 20\% CFH; 10\% BCF) & $40.982 \mathrm{a}$ & $51.874 \mathrm{a}$ & $70.654 \mathrm{a}$ & $6.238 \mathrm{~b}$ \\
\hline
\end{tabular}

Note: Averages followed by the same letter in the column do not differ from each other by the Scott \& Knott test at $5 \%$ probability.

Caption: S (sawdust); CFH (fruit peel / vegetables); BCF (coffee grounds and filter).

The high value of the $\mathrm{C} / \mathrm{N}$ ratio in the treatments may be due to the raw material used (sawdust, high $\mathrm{C} / \mathrm{N}$ ratio), unfavorable to the process, making degradation difficult. This type of residue is usually bulky and difficult to be degraded, unless it is ground, which could not be achieved in this work. This can increase the composting period. The results obtained in this study show that all treatments comply with the Brazilian legislation on the organic matter content, which requires that the minimum amount of organic matter for the compound is $40 \%$.Composting can be an efficient technology for the treatment and recycling of organic solid waste. However, the low ambient temperatures in the composting process, the high $\mathrm{C} / \mathrm{N}$ ratio of the sawdust, the proportion of residues used in the formation of the compost and the volume of the material may have influenced the composting process.

The factors that influence composting are: microorganisms present in the compost, temperature, humidity, aeration, granulometry, $\mathrm{C} / \mathrm{N}$ ratio and $\mathrm{pH}$ factor. The microorganisms are responsible for the decomposition of the material being composted, without them there is no way to do the composting. The temperature is related to the 
thermal destruction of the microorganisms, temperatures above $65{ }^{\circ} \mathrm{C}$, the process is delayed. The humidity of the compound is important; you cannot have too little or too much moisture in it, because it can disrupt the decomposition of organic matter. Without oxygen, there is no life in the compound, so decomposition is slower and unpleasant odors will appear. In the beginning it is necessary to stir more frequently and then from time to time. When preparing the material it is necessary that the particle size is the smallest possible, because the smaller the particle size, the faster the composting process. The ideal $\mathrm{C} / \mathrm{N}$ ratio to make the compound is in the range $25 / 1$ to $35 / 1$, that is 25 parts of carbon for each of the nitrogen. As composting is done by the aerobic method, this causes the compound to become alkaline throughout the process [11]. The diversity and concentration of the nutrients present in the compound are related to the intensity of the microbiological activity of the decomposing microorganisms and their population. For the metabolic activities of the microorganisms to occur, it is necessary to have several macro and micronutrients in the organic residues. Among them, the most important are nitrogen and carbon, their presence is a limiting factor in the composting process, carbon is a basic source of energy for vital activities and nitrogen is necessary for protoplasmic reproduction of microorganisms. Palious waste is a source of carbon and green materials are sources of nitrogen [6].

\section{Conclusion}

There are no reference values for macronutrient and micronutrient results, as far as $\mathrm{C} / \mathrm{N}$ results are concerned, the data were outside the standards established by Brazilian legislation, but organic matter and $\mathrm{pH}$ variables met the requirements.

In general, treatments 1 and $2(50 \%$ of sawdust $+35 \%$ of organic residue $+15 \%$ of coffee grounds and $50 \%$ of sawdust $+30 \%$ of organic residue $+20 \%$ of coffee grounds, respectively) presented the best nutritional values in relation to the other treatments, influenced by the lower percentage of sawdust.

Therefore, it is necessary to carry out more studies with smaller ratios of sawdust, to see the viability of the composting process. Since the proportion of $30 \%$ of green material and $70 \%$ of brown material can not be used as a standard for composting.

\section{References}

[1] Recycle, "Composition of Brazilian garbage in regard to Veja. Recicloteca - Information Center on Recycling and Environment." Available: http://www.recicloteca.org.br/coleta-seletiva/a-composicao-do-lixo-brasileiro/ [Accessed 31 May. 2016 ], 2011. B. Calixto, "Garbage that does not end. Season Magazine." Available: http://epoca.globo.com/colunas-e-blogs/blog-doplaneta/noticia/2015/07/lixao-que-nao-acaba-mais.html. [Accessed 30 May 2016], 2015.

[3] B. CALIXTO, "17 million people do not have access to regular garbage collection in Brazil. Season Magazine, 2016." Available: http://epoca.globo.com/colunas-e-blogs/blog-do-planeta/noticia/2016/02/17-milhoes-de-pessoas-nao-tem-acesso. [Accessed 30 May 2016], 2016.

[4] L. A. A. Pereira and M. L. Fialho, "Sustainability management: Optimized composting in organic solid waste with the use of enzymatic methodology in the implantation of a waste composting plant in the Municipality of Santa Juliana / MG," International Journal of Knowledge Engineering and Management, vol. 2, pp. 52-85, 2013.

ABNT, "Brazilian association of technical standards - NBR 13591. Rio De Janeiro," 1996.

N. J. T. Pereira, Composting manual: Low-cost process, 4th ed. Viçosa, MG: UFV, 2014.

A. J. Mendes, "Importance of composting for the environment and people's health. JE online, 2013." Available: http://jeonline.com.br/coluna/140/importancia-da-compostagem-para-o-me-ambiente-e-saude-das-pessoas. [Accessed 28 Jun $2017], 2013$.

[8] M. U. C. Nunes, Technical circular 59. Composting of waste to produce organic fertilizer on small property. Aracaju, SE: Embrapa Coastal Tracks, 2009.

[9] J. L. D. S. Nunes, "Organic fertilizers: Organic fertilizer: Agrolink, 2016." Available:

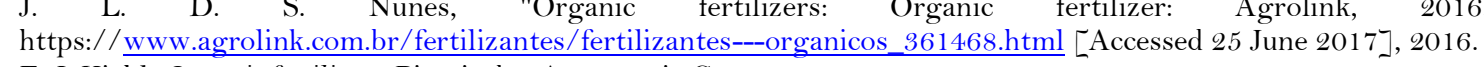

[10] E. J. Kiehl, Organic fertilizers. Piracicaba: Agronomic Ceres, 1985.

$[11] \quad$ B. P. Custodio, C. Mersoni, and C. A. Schneider, "Practical composting handbook. Municipal Secretary of Environment, SMMA, 2011." Available: http://www.garibaldi.rs.gov.br/upload/page file/manual-pratico-de-compostagem-net-final.pdf. $\ulcorner$ Accessed 25 May 2016], 2011.

[12] A. C. Malvestio, C. S. Pires, F. W. K. Heng Mo, and G. D. M. Capestrani, Basic composting manual - series: Knowing the residues. University of São Paulo, 2009.

[13] M. I. D. S. Carmo, "Manual of domestic composting practice. City Hall of Paços De Ferreira, 2015." Available: http://agriculturaurbana.org.br/boas_praticas/textos_compostagem/Manual_Compostagem_portugal.pdf. [Accessed 24 May $2016], 2015$.

[14] I. Ishimura, S. M. Yamamoto, C. D. Santos, and M. A. Oliveira, Organic olericulture program. São Paulo: SENAR-AR / SP, 2009.

[15] G. L. R. Fetti, Evolution of organic matter during the composting process. 2013. Student of the postgraduate course in microbiology of IBILCE-UNESP. São José Do Rio Preto: SP, 2013.

[16] T. P. D. Moraes, Study of the physical-chemical aspects of composting based on the manioc bark. 2014. 42 f. Course completion Work (Technologist in Environmental Management). Medianeira: Federal Technological University of Paraná / Medianeira Campus, 2014.

[17] C. D. Cruz, "Genes: A software package for analysis in experimental statistics and quantitative genetics," Acta Scientiarum Agronomy, vol. 35, pp. 271-276, 2013. Available at: https://doi.org/10.4025/actasciagron.v35i3.21251.

[18] J. P. Arrigoni, G. Paladino, L. A. Garibaldi, and F. Laos, "Inside the small-scale composting of kitchen and garden wastes: Thermal performance and stratification effect in vertical compost bins," Waste Management, vol. 76, pp. 284-293, 2018. Available at: https://doi.org/10.1016/j.wasman.2018.03.010.

[19] N. Abdullah, N. L. Chin, M. N. Mokhtar, and F. S. Taip, "Effects of bulking agents, load size or starter cultures in kitchen-waste composting," International Journal of Recycling of Organization Desperdício Agriculture, vol. 2, p. 3, 2013.

[20] B. K. Adhikari, A. Trémier, and J. Martinez, "Home composting of organic waste - part 1: Effect of home composter design," International Journal of Environmental Technology and Management, vol. 15, pp. 417-437, $2012 \mathrm{a}$.

[21] B. K. Adhikari, A. Trémier, J. Martinez, and S. Barrington, "Home composting of organic waste-part 2: Effect of management practices," International Journal of Environmental Technology and Management, vol. 15, pp. 438-464, 2012.

[22] R. Barrena, X. Font, X. Gabarrell, and A. Sánchez, "Home composting versus industrial composting: Influence of composting system on compost quality with focus on compost stability," Waste Management, vol. 34, pp. 1109-1116, 2014. Available at: https://doi.org/10.1016/j.wasman.2014.02.008.

[23] F. Storino, J. S. Arizmendiarrieta, I. Irigoyen, J. Muro, and P. M. Aparicio-Tejo, "Meat waste as feedstock for home composting: Effects on the process and quality of compost," Waste Management, vol. 56, pp. 53-62, 2016. Available at: https://doi.org/10.1016/j.wasman.2016.07.004.

[24] F. Storino, S. Menéndez, J. Muro, P. M. Aparicio-Tejo, and I. Irigoyen, "Effect of feeding regime on composting in bins," Compost Science Eं Utilization, vol. 25, pp. 71-81, 2017. Available at: https://doi.org/10.1080/1065657x.2016.1202794.

[25] Instituto Nacional de Meteorologia (INMET), "Available in: Andlt." Available: http://www.inmet.gov.br/portal/, 2017. 
[26] C. M. Barroso, L. B. Franke, and I. B. I. Barros, "Substrate and light on seed germination of queen of the abyss," Horticultura Brasileira, vol. 28, pp. 236-240, 2010.

[27] C. S. D. S. Souza, M. C. Alves, R. M. M. D. Castilho, M. L. D. S. Silva, and F. M. Fernandes, "Chemical properties of vegetable materials used in composting and of different substrates," Agronomic Culture, vol. 16, pp. 47-54, 2007.

[28] A. N. Kampf, Commercial production of ornamental plants. Guaíba: Agropecuária, 2000. 